http://jmscr.igmpublication.org/home/ ISSN (e)-2347-176x ISSN (p) 2455-0450 crossref DOI: https://dx.doi.org/10.18535/jmscr/v7i8.44

\title{
A Study of Effect of Fluid Restriction on Mortality and Morbidity Pattern in Term Neonates with Perinatal Asphyxia Admitted In NICU, KGH
}

\author{
Authors \\ Dr Prema Sekhar ${ }^{1}$, Dr Pushpa Priyanka ${ }^{2}$ \\ ${ }^{1,2}$ Post Graduate, Department of Pediatrics, Andhra Medical College
}

\begin{abstract}
Introduction: Perinatal Asphyxia is one of the commonest Neonatal problems and contributing significantly to Neonatal Morbidity and Mortality. This study is done for controlling the consequences of Hypoxic Ischaemic Encephalopathy following Perinatal Asphyxia with careful management of fluid and avoidance of Cerebral Edema.

\section{Aims and Objectives}

1. To assess the effects of Fluid Restriction (FR) and Full Fluid (FF) administration on mortality and morbidity patterns in term neonates with Perinatal Asphyxia.

2. Comparison of occurrence of seizures in FR and FF group.

Materials and Methods: This is prospective study conducted in babies admitted in NICU, KGH with Perinatal Asphyxia from May2018 to May2019. 62 babies were included in this study and 31 were subjected to FR. (2/3 ${ }^{\text {rd }}$ of total requirement)

Inclusion Criteria: Term neonates $>37$ weeks with Perinatal Asphyxia (In Born, Out Born with $A P G A R<6)$ at 5 min admitted in $\mathrm{KGH}$

\section{Exclusion Criteria}

1. Preterm babies

2. Babies with Congenital Malformations, Renal Failure, Suspected Metabolic Disease, MAS, Congenital Infections.

Results: 62 babies admitted in NICU are grouped into FR (31) and FF(31) of that $17 \%$ Mortality noted in FR group and 3.5\% FF group. In FR group progression of HIE-II to HIE-III is more and there is less frequency of seizures in FR group

Conclusions: FR group showed increased encephalopathy and more chances of AKI In fluid restricted group and no significant change in mortality. There is decreased frequency of seizures in FR group.
\end{abstract}

\section{Introduction}

Perinatal asphyxia is one of the commonest neonatal problems contributing significantly to neonatal mortality and morbidity. It is the $2^{\text {nd }}$ most important cause of neonatal death after infection accounting for $30 \%$ mortality

Approximately $15-20 \%$ who exhibit HIE actually die during newborn period.
Current recommendation is to control consequences of hypoxic ischemic encephalopathy by careful management of fluids with avoidance of fluid overload with hope of avoiding cerebral edema.

Incidence of hypoxic ischemic encephalopathy was estimated to be 1 per 1000 live births. 


\section{Aims and Objectives}

- To assess the effect of fluid restriction and full fluid administration on mortality and morbidity pattern in full term neonates with perinatal asphyxia

- Comparison of occurrence of seizures in full fluid and fluid restricted group

\section{Materials and Methods}

- This is prospective study done in NICU, KGH conducted from may 2018-may 2019 on 62 babies. Half of them were subjected to fluid restriction $\left(2 / 3^{\text {rd }}\right.$ of total requirement) and monitored for $1^{\text {st }} 3$ days.

\section{Inclusion Criteria}

- Term neonates (>37weeks with perinatal asphyxia (inborn and outborn with APGAR $<6$ at $5 \mathrm{~min}$ admitted in $\mathrm{KGH}$

\section{Exclusion Criteria}

- Preterm babies

- Babies with congenital malformations, renal failure, suspected metabolic disease, MAS, congenital infections.

\section{Methodology}

- Ethics committee approval taken.

- Detailed history and physical examination at admission

- Parameters included are weight, HIE staging, urine output, seizures and neurological examination at the time of discharge and their outcome

- In addition to routine investigations babies sampled for blood urea, creatinine, electrolytes and other imaging modalities like CT and MRI brain done when indicated.

\section{Study Variables}

- Dependent variables: outcome (discharge/ death)

- Independent variables: gestational age, sex, place of delivery, medical illness of mother.

- Statistical methods:

Babies were monitored and results tabulated in Excel chart and CHI- square test and student " $\mathrm{t}$ " test was applied and results noted. Z-test was used to test the significant difference between two proportions. $\mathrm{p}$ value $<.05$ was considered for statistical significance

\section{Results}

APGAR was noted for all neonates at 1 and 5 minutes

The mean APGAR score at 1 min was 4 and 3.9 respectively for FF and FR groups.

Mean APGAR score at 5 min was 4.90 and 4.94 for FF and FR group.

APGAR score at presentation to hospital

\begin{tabular}{|c|c|c|c|c|c|}
\hline VARIABLE & GROUP & $\mathbf{N}$ & $\begin{array}{l}\text { ME } \\
\text { AN }\end{array}$ & $\begin{array}{c}\text { RANG } \\
\text { E }\end{array}$ & $\begin{array}{c}\text { 'p' } \\
\text { value }\end{array}$ \\
\hline \multirow{3}{*}{$\begin{array}{l}\text { APGAR at } 1 \\
\min \end{array}$} & Full Fluid & 31 & 4.00 & $3-5$ & \multirow[t]{3}{*}{0.473} \\
\hline & $\begin{array}{c}\text { Fluid } \\
\text { Restriction }\end{array}$ & 31 & 3.90 & $3-5$ & \\
\hline & Total & 62 & 3.95 & $3-5$ & \\
\hline \multirow{3}{*}{$\begin{array}{l}\text { APGAR at } 5 \\
\text { min }\end{array}$} & Full Fluid & 31 & 4.90 & $3-5$ & \multirow[t]{3}{*}{0.820} \\
\hline & $\begin{array}{c}\text { Fluid } \\
\text { Restriction }\end{array}$ & 31 & 4.94 & $4-6$ & \\
\hline & Total & 62 & 4.92 & $3-6$ & \\
\hline
\end{tabular}

All the babies were in stage II HIE at the time of admission and the progression of encephalopathy was documented with fluid intervention.

At the end of 3 days 1 baby (3.2\%) progressed to stage III in FF group and 7 babies (23.8\%) in FR group.

$\mathrm{p}$ value was statistically significant that is 0.035 .

HIE (SARNAT AND SARNAT) status of newborn in $1^{\text {st }}$ 3days of intervention

\begin{tabular}{|l|c|c|c|c|}
\hline \multirow{2}{*}{ Day 1 } & Group & \multicolumn{2}{|c|}{ 'P' } & 'P' \\
\cline { 3 - 4 } & value \\
\hline & Full fluid & $31(100 \%)$ & \\
\cline { 2 - 4 } & $\begin{array}{c}\text { Fluid } \\
\text { restriction }\end{array}$ & $31(100 \%)$ & \multirow{2}{*}{} \\
\hline day 2 & Full fluid & $30(96.8 \%)$ & $1(3.2 \%)$ & \multirow{2}{*}{.035} \\
\cline { 2 - 4 } & $\begin{array}{c}\text { Fluid } \\
\text { restriction }\end{array}$ & $27(90 \%)$ & $3(10 \%)$ & \\
\hline Day 3 & Full fluid & $30(100 \%)$ & & \multirow{2}{*}{} \\
\cline { 2 - 4 } & $\begin{array}{c}\text { Fluid } \\
\text { restriction }\end{array}$ & $25(86.2 \%)$ & $4(13.8 \%)$ & \\
\hline
\end{tabular}

30 babies in both groups had seizures within 24 hours of delivery and remaining 2 had seizures within 48 hours. 
Frequency of seizures was found to be higher in FF group.

The frequency and duration of antiepileptics was higher in FF group but the need for $>1$ antiepileptic was higher in FR group.

Frequency of seizures in $1^{\text {st }} 3$ days of fluid management

\begin{tabular}{|c|c|c|}
\hline & < 5seizures & $>$ 5 seizures \\
\hline Full fluid & 27 & 4 \\
\hline Fluid restriction & 28 & 3 \\
\hline
\end{tabular}

The average day of initiation of breastfeeding in FF group was 6.3 days and FR group 7.35 days. The average day of discharge with FF group was 8.83 days and FR group was 10.5 days.

Day of initiation of breastfeeding and day of discharge

\begin{tabular}{|c|c|c|c|c|c|}
\hline & $\begin{array}{c}\text { GRO } \\
\text { UP }\end{array}$ & $\mathbf{N}$ & $\begin{array}{c}\text { MEA } \\
\mathbf{N}\end{array}$ & $\begin{array}{c}\text { RANG } \\
\text { E }\end{array}$ & $\begin{array}{c}\mathbf{p} \\
\text { value }\end{array}$ \\
\hline \multirow{2}{*}{$\begin{array}{ll}\text { Day } & \text { of } \\
\text { discharge }\end{array}$} & FF & 30 & 8.83 & $7-15$ & \multirow[t]{2}{*}{0.011} \\
\hline & FR & 26 & 10.50 & $6-17$ & \\
\hline \multirow{2}{*}{$\begin{array}{l}\text { Day of } \\
\text { breastfeeding }\end{array}$} & $\mathrm{FF}$ & 30 & 6.30 & $4-9$ & \multirow[t]{2}{*}{0.067} \\
\hline & FR & 26 & 7.35 & $4-12$ & \\
\hline
\end{tabular}

At discharge on neurological examination 2 infants were abormal in FF group and 3 infants were abnormal in FR group ( $p$ value 0.524 ) which is statistically not significant.

\section{Neurological status at discharge}

\begin{tabular}{|l|c|c|c|}
\hline \multirow{3}{*}{ GROUP } & \multicolumn{2}{|c|}{$\begin{array}{c}\text { NEUROLOGICAL } \\
\text { EXAMINATION }\end{array}$} & \\
& \multicolumn{2}{c|}{ E VALUE } \\
& AT DISCHARGE & \\
\cline { 2 - 3 } & NORM & ABNORM & \multirow{2}{*}{0.524} \\
& AL & AL & \\
\hline FULL FLUID & 28 & 2 & \multirow{2}{*}{$0.5 \%)$} \\
& $(93.3 \%)$ & $(6.7 \%)$ & \\
\hline FLUID & 23 & 3 & \\
RESTRICTION & $(88.5 \%)$ & $(11.5 \%)$ & \\
\hline
\end{tabular}

From FF group 1 baby expired with HIE and multiorgan dysfunction. This baby had APGAR score $<3$.

From FR group 5 babies out of which 3 had multiorgan dysfunction. Among the 5 babies of FR group, 2 babies had APGAR score $<=3$ and other 3 babies had score of 4-6.
Study outcome

\begin{tabular}{|l|c|c|c|}
\hline \multirow{2}{*}{ GROUP } & \multicolumn{2}{|c|}{ OUTCOME } & \multirow{2}{*}{ p } \\
\cline { 2 - 3 } & discharge & death & VALUE \\
\hline \multirow{3}{*}{ FULL FLUID } & 30 & 1 & 0.086 \\
\hline FLUID & $(96.8 \%)$ & $(3.2 \%)$ & \\
RESTRICTION & 26 & 5 & \\
\hline TOTAL & $(83.9 \%)$ & $(16.1 \%)$ & \\
& 56 & 6 & \\
$(90.3 \%)$ & $(9.7 \%)$ & \\
\hline
\end{tabular}

In FF group 2 babies CT scan and in FR group 3 babies CT scan was suggestive of cerebral edema.

\section{CT scan finding in $1^{\text {st }} \mathbf{4 8}$ hours life}

\begin{tabular}{|l|r|r|r|r|}
\hline & IMAGING & GROUP & NORMAL & EDEMA \\
\hline DAY & $\mathrm{CT}$ & FULL FLUID & $27(96.4 \%)$ & $1(3.6 \%)$ \\
\cline { 3 - 5 } 1 & & FLUID & $27(93.1 \%)$ & $(6.9 \%)$ \\
& & RESTRICTION & & \\
\hline DAY & $\mathrm{CT}$ & FULL FLUID & $1(50 \%)$ & $1(50 \%)$ \\
\cline { 3 - 5 } 2 & & FLUID & $1(50 \%)$ & $1(50 \%)$ \\
& & RESTRICTION & & \\
\hline
\end{tabular}

TOTAL ADMISSIONS- 700

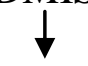

TERM BABIES - 400

BIRTH ASPHYXIA- 120

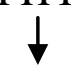

ELIGIBLE FOR STUDY- 62

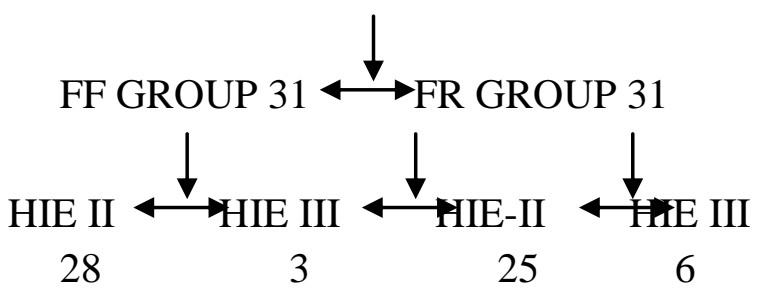

\section{Conclusion}

> In our study FR group showed significant progression of encephalopathy in first 3 days of fluid management when compared to unrestricted group.

$>$ The study showed a forward trend towards increased mortality with fluid restriction.

$>$ The frequency of seizures was less in fluid restricted group.

$>$ This study showed that fluid restriction did not show any advantages in the management of babies with birth asphyxia and in contrast has increased the morbidity associated with birth asphyxia. 


\section{References}

1. Yu P L., Jin LM., Seaman H.,Yang Y J., Tong H X.,2000 "Fluid therapy of acute brain edema in children". Pediatric Neurology; 22:298-301.

2. Volpe J J., 2001., "Hypoxic ischemic encephalopathy”., Neurology of Newborn: unit III;217-331: 4th edition: printed by W.B. Saunders Company.

3. Sanjay, Aurora, Evan , Y, Snyder.,5th edition 2004 "Perinatal Asphyxia" in: John P. Cloherty et al., "Manual of neonatal care"., Lippincott Williams and Wilkins; chapter 27:536-555.

4. Aggarwal, R., Deorari, A,K., Paul,V, K., 2001., "Post-resuscitation management of asphyxiated neonates"., Indian Journal of Pediatrics., dec;68(12):1149-1153.

5. Report of the National Neonatal Perinatal Database (National Neonatology Forum India)2000 22. Gary, F., Cunningham Kenneth., J, Leveno., Steven, L., et.al., "The Newborn infant". Williams Obstetrics; Mc Graw Hill; 22nd edition: 2005; chapter 28:633-648.

6. Barbara, J, Stoll., Robert, M, Kleigman.,2004 "Nervous system disorders". In : Richard, E, Behrman., Robert, M, Kleigman., Hal,B, Jenson., "Nelson Text Book of Pediatrics", Saunder an imprint of Elsevier., $21^{\text {st }}$ edition., chapter88:561-569.

7. Rajeshwar Reddy A., Praveen Kumar.,2004., "Follow-up of Neonates with Pernatal asphyxia". Journal of Neonatology: april to june:18:22-26.

8. Arvind Saili., 2000., "Clinical profile Hypoxic ischemic encephalopathy”. Pediatrics Today; 10:661-7.

9. The Apgar score policy statement AAP.,2006., "Committee of the fetus and new born"., ACOG., and Committed on Obstetric practice”., Pediatrics., april117(4) : $1444-1447$.
10. Kecskes, Z., Healy G, Jensen,A ., 2005 "Fluid restriction for term infants with hypoxic ischemic encephalopathy following perinatal asphyxia" Cochrane database systematic review july 23; 3 (pubmed in process). 